\title{
INDEPENDENT AGENCIES: FORM AND SUBSTANCE IN EXECUTIVE PREROGATIVE
}

\author{
GLIEN O. ROBINSON*
}

I

Among other things, the Supreme Court's decision in Morrison $v$. Olson, ${ }^{1}$ upholding Congress's authorization of independent counsel to imvestigate and prosecute high-ranking government officials for violation of federal criminal laws, presumably will chill speculation that the Supreme Court is prepared to rethink the constitutionality of the imdependent agencies. Prior to the 1980 s the constitutionality of the independent agencies had generally been thought secure on the strength of Humphrey's Executor. ${ }^{2}$ Despite recurrent criticism of that decision, ${ }^{3}$ there was no basis to think it was especially vulnerable. The Court's recent fascination with separation of powers, ${ }^{4}$ however, invited speculation about some radical reconstruction in administrative law, notably includimg deconstruction of the independent agencies.

One of the cases inviting such speculation was the Court's decision in Immigration \& Naturalization Service v. Chadha, ${ }^{5}$ invalidating the legislative veto. While not directed at administrative agencies, Chadha could be taken as a sign of fresh concern about agency rulemaking as a form of non-article I lawmaking. ${ }^{6}$ A year earkier the Court's Northern

* John C. Stennis Professor of Law, University of Virginia. FCC Commissioner, 1974-1976. Most of my biases on this subject antedate ny experience at the FCC and for better or worse have survived it.

1. 108 S. Ct. 2597 (1988).

2. Humphrey's Executor v. United States, 295 U.S. 602 (1935).

3. See Miller, Independent Agencies, 1986 SuP. CT. REV. 41, 93. Miller's criticism is only slightly harsher than many others'. See, e.g., Bruff, Presidential Power and Administrative Rulemaking, 88 YALE L.J. 451, 479-80 (1979); Strauss, The Plaee of Agencies in Govermment: Separation of Powers and the Fourth Branch, 84 CoLUM. L. REV. 573, 611-12 (1984).

4. See generally Krent, Separating the Strands in Separation of Powers Controversies, 74 VA. L. REv. - (forthcoming, 1988); Strauss, Formal and Functional Approaches to Separation-of-Powers Questions-A Foolish Inconsistency?, 72 CORNELl L. REv. 488 (1987) (discussing the Court's opinions in Bowsher v. Synar, 478 U.S. 714 (1986), and Commodity Futures Trading Comm'n v. Schor, 478 U.S. 833 (1986), both of which addressed separation of powers issues in comection with the limits of congressional powers).

5. 462 U.S. 919 (1983).

6. The Court denied that its decision invalidated legislative-type activity conducted by agencies. It waved aside the objection that forbidding a legislative veto over the Attorney General's 
Pipeline decision, ${ }^{7}$ holding that non-article III tribunals cannot adjudicate "private rights," threatened soine agency adjudications. In themselves, Chadha and Northern Pipeline imply only vague threats to administrative agencies. After all, no one expects the Court to follow the logic of Chadha to the extent of mvalidatimg the exercise of legislative power by all administrative agencies (say, by reviving the nondelegation doctrine). Furtherinore, if Northern Pipeline has any future at all, ${ }^{8}$ it should not affect the mine-run of agency adjudications (imsofar as they deal with "public" rather than "private" rights). In any case the implications of these decisions are not special to imdependent agencies but extend to rulemaking and adjudication by mdependent and executive agency alike.

In 1986, however, the Court's decision in Bowsher v. Synar ${ }^{9}$ appeared to take dead aim at the independent agencies with its holding that the Coinptroller General could not constitutionally exercise executive powers because he was an agent of Congress not subject to presidential control. Though the Court demed any threat to independent agencies by drawing a rather fine distmction between an agent of Congress and an independent administrative agency, ${ }^{10}$ it seemed inevitable that Bowsher

decision to suspend deportation would in effect sanction lawmaking by the Attorney General-and by extension any agency having comparable delegated "legislative" authority. 462 U.S. at 953 n.16. The Court reasoned that while administrative rulennaking might soinetimes "reseinble 'legislative' action," it was "not subject to the approval of both Houses of Congress and the President for the reason that the Coustitution does not so require." Id. This is entirely question-begging. See Elliott, INS v. Chadha: The Administrative Constitution, the Constitution, and the Legislative Veto, 1983 SUP. CT. REv. 125, 146. Of course, had the Court acknowledged that agency ruleinaking was "lawinaking" within the ineaning of article I, this would affect more than just the independent agencies. However, in terms of preserving presidential veto prerogatives, ouly the delegation of lawmaking to independent agencies should be a concern, since executive lawmaking is assumed to be subject to presidential control.

7. Northern Pipeline Constr. Co. v. Marathon Pipe Lime Co., 458 U.S. 50 (1982).

8. More recently the Court, in Schor, 478 U.S. at $852-56$, repudiated the formalist approach of Northern Pipeline in favor of a more flexible, functional one along the lines of Crowell v. Benson, 285 U.S. 22 (1932). Crowell approved non-article III adjudication of "private" rights so long as the essential attributes of the judicial power were preserved through judicial determination of legal issues and review agency factfindings. Id. at 60-62. Since Crowell, even the judicial review requirement has been watered down, permitting judicial deference to adjudication of all legal and factual issues. See Fallon, Of Legislative Courts, Administrative Agencies, and Article III, 101 HARv. L. Rev. 916, 923-32 (1988).

9. Bowsher v. Synar, 478 U.S. 714 (1986).

10. The Court distinguished the Comptroller General from independent agency members on the ground that the former was subject to direct removal from office by Congress, whereas independent agency members were removable by Congress only for certain causes. 478 U.S. at 725 n.4. Justice Stevens, concurring, thought that the Comptroller General's status as an arm of Congress did not turn solely on the removal power. Id. at 736. Justice White, dissenting, observed that in fact Congress could not remove the Comptroller General except by a joint resolution subject to presidential veto; therefore, Justice White concluded that, unlike the situation in Chadha, the exercise of executive powers by the Comptroller General did not encroach on executive prerogatives. He also 
would force a fresh look at Hiumphrey's Executor and the constitutional status of the independent agencies.

I suppose it has, if one can construe Olson to be that fresh look, though the outcoine is not quite what one might predict froin Bowsher. Part of Olson deals with coustitutional issues that are not here pertinent; ${ }^{11}$ on the relevant part a brief comment will suffice.

The separation of powers attack on independent counsel was twofold. The first claim rested on the absence of an unconditioned presidential reinoval power; the second on Congress's limitation on the executive prerogative to investigate and prosecute violations of the law.

The Court's response to these claims is noteworthy on several counts, not least of which is its abandonment of the formalistic approach that characterized some of the Court's earher separation of powers decisions. ${ }^{12}$ Apropos of the subject of this essay, the opimion is particularly important insofar as it avoids any suggestion that the independent counsel problem is special. The Court refused to draw any generic distinction between "purely executive officials" and functions (such as investigation and prosecution) on the one hand, and "quasi-legislative" or "quasi-judicial" officials/functions on the other. The rejection of this categorical distinction not inerely reaffinns Humphrey's Executor but goes beyond it. ${ }^{13}$ Congressional restrictions on the removal power are no longer to be tested by artful defimitions of powers (as in Humphrey's Executor), but are to be judged by a pragmatic assessment of whether the restrictions unreasonably burden the President's power to ensure the "faithful execution of the laws." Conditioning removal of independent counsel on a finding of "good cause" is not necessarily such a burden. Extending the saine pragmatic approach to the general separation of powers issue, the Court found no unreasonable interference with executive prerogative since the President (through the Attorney General) retained a degree of control over the occasion for appointment of counsel as well as the power of removal for cause.

argued that the functions assigned to the Comptroller General did not interfere with or usurp the President's constitutional prerogatives. Id. at 759.

11. A central issue in the case revolved around the appointment of the independent counsel by a special court (acting on the initiative of the Attorney General, who determines whether investigation by such counsel is warranted). Article II authorizes Congress to "vest the Appointment of such inferior Officers . . . in the President alone, in the Courts of Law, or in the Heads of Departments." The question was whether independeut counsel were "inferior officers." $108 \mathrm{~S}$. Ct. at 2608-11. A separate issue was whether under article III the special court could be authorized to determine the jurisdiction of counsel and perform certain supervisory tasks-argued to be nonjudicial functions. The Court answered both questions in the affirmative. $108 \mathrm{~S}$. Ct. at 2611-15.

12. See $108 \mathrm{~S}$. Ct. at $\mathbf{2 6 1 6 - 2 2}$ (discussing the formalistic approach taken in Humphrey's Executor, Bowsher and Chadha).

13. This point is noted critically by Justice Scalia in dissent. See $108 \mathrm{~S}$. Ct. at $2636-37$. 
I said that Olson presumably will end speculation about the Court overturning Humphrey's Executor. One might argue, however, that imdependent agencies are different from independent counsel because the functions of the former are more central to the President's executive prerogative and hence require greater presidential power of control (including the power of unconditional removal). The fact that independent counsel are (by the Court's interpretation of article I) "inferior officers" might give some support to this distinction-the notion bemg that principal officers (including all members of the mdependent agencies) share the presidential prerogative more immediately than inferior officers and hence should be subject to plenary presidential control.

I think this is not a winning argument. Of course the functions of independent agencies and independent counsel are different. However, the key differences concern functions that are not executive, but legislative and judicial. Whatever separation of powers problems are raised by the fact that agencies make law and adjudicate cases, these are not interferences with executive prerogative. Nor does the Court's opinion in Olson suggest that the executive prerogative turns on whether inferior or principal officers are involved. What it does suggest is that a conditioned reinoval power may constitute sufficient control to preserve the essential executive prerogative-particularly when it is accompanied by some control over appointments (which of course is the case with all imdependent agency members). Moreover, Olson suggests that all forms of presidential control should be considered. As I will suggest, the President's powers of control are at least as great as practical circumstances allow him to exercise.

In any event, the pragmatic test of Olson invites us to consider a question too often iguored: in terms of political power and its practical exercise, what really turns on formal executive prerogative-what does "independence" really mean? This imtensely practical question is the concern of this essay.

\section{II}

Justice Holmes once admomished us to think things, not words. ${ }^{14}$ This non-Wittgensteinian sentiment may not be altogether fashionable in inodern philosophical circles, but it is still useful counsel, and it is nowhere more pertinent than to the commentary on separation of powers im general and independent agencies in particular. Discussion about

14. "We inust think things not words, or at least we inust constantly translate our words into the facts for which they stand, if we are to keep to the real and the true." O.W. HoLMES, Law in Science and Science in Law, in COLLECTED LeGAL PAPERS 210, 238 (1921). 
whether the existence of independent agencies violates separation of powers usually takes place on a level of generality that is unhelpful in defining the terms of relationship between the agencies and the President-or, for that inatter, between the agencies and the courts or the agencies and Congress. In the two latter contexts, however, "independence" is essentially an einpty concept. ${ }^{15}$ For all of the eternal debate about terminating the independence of the agencies and "restorimg" executive prerogatives with respect to their functions, it is remarkable how seldom the debaters pause to ask: what, if anything, turns on that restoration?

This question is dauntingly general in its scope. It is useful to narrow the field of inquiry by considering those inatters that by law should not, and presuinably would not, be affected by the agency's organizational structure or changes therein. We can start with formal adjudicatory matters, required either by statute or constitutional due process to be decided solely on the basis of a hearing record. Although the need to protect the integrity of the adjudicatory process is sometimes offered as a reason for agency independence, in fact it is not one. Adjudications are insulated froin influences outside the hearing process by constitutional and statutory norms of due process that bind the President no less than the ordinary citizen. We have no evidence that these norms are violated by the former inore than by the latter. Adjudications at the FDA (an executive agency) are not, so far as I am aware, any more subject to extra-record executive influence than are those of the FTC.

This conclusion is not altered by the fact that decisionmakers may have discretion even in adjudicatory inatters, because such discretion is not properly subject to direct influence by anyone-or, in theory, anything-outside the hearmg process. ${ }^{16}$ A President or his subordinate may properly infiuence such adjudicatory decisions by appointing persons who can be rehed upon to use their discretion according to the desired end; but, of course, this inethod of influence extends to independent and executive agency officers alike. There is, I suppose, some possibility that executive officers subject to peremptory reinoval will be inore biased towards White House views, but this assumes a closer degree of White

15. To say that independent agencies are "independent" of the courts or Congress does not, of course, distinguish them from executive agencies. All agencies are independent from Congress and the courts in a structural sense, and they are all "dependent" in the sense of being subject to legislative enactments or judicial decrees.

16. See, e.g., Pillsbury Co. v. FTC, 354 F.2d 952 (5th Cir. 1966) (legislative influence on agency adjudication improper); WKAT, Inc. v. FCC, 296 F.2d 375 (D.C. Cir.) (hearing tainted by ex parte communications from one of the parties), cert. denied, 368 U.S. 841 (1961); Ohio Bell Tel. Co. v. Public Utilities Comm'n of Ohio, 301 U.S. 292 (1937) (adjudicatory decision improperly relied on evidence not in hearing record). 
House monitoring of individual cases than I think is plausible. ${ }^{17}$

We can then exclude all fornal adjudicatory contests from the class of choices where organizational forn counts. But excluding consideration of adjudications in the general debate over policy-setting prerogatives is relatively unimportant. If a President can control an agency's policies or enforcennent agenda, he has httle reason to care about individual adjudications. It is upon these areas of executive influence that our attention inust be focused.

For reasons just noted, the President's prerogatives as to both policy and enforcement priorities are not unlimited. Even the President is bound to observe such processes and such substantive legal standards as Congress sets for the agency's policy choices. Presidential-power enthusiasts soinetimes forget that the President's constitutional responsibility is to "see that the laws are faithfully executed," and that it is Congress that makes "the laws." 18

Althougl the President's own constitutional prerogatives witl regard to law enforcement may constrain Congress's power to specify the ways and means of presidential enforcement, that constraint has yet to be defined. ${ }^{19}$ For practical purposes Congress's power to control pohicy discretion is subject only to the President's power to veto the legislation itself. For instance, if Congress, by statute, directs the Department of Transportation to promnlgate rules requiring installation of airbags in automobiles, the President may not direct the Department to do otherwise. Pretermitting his opportunity to veto the legislation itself, the President's influence is limited by the terns of the statute. It makes no difference that the Department is an executive agency. That the Secretary of Transportation reports to the President gives the latter a degree of influence over discretionary clioices, but the President lias no inherent constitutional authority to redefine a clear congressional mandate as to what those choices are.

Even where there is a large area of administrative discretion, the presidential prerogative is constrained by the outer limits of administrative discretion embedded in the statutory standards. Suppose Congress directs the Department of Transportation to promnlgate rules requiring installation in automobiles of a restraint system that "best ensures the

17. Any overt threat of removal as a sanction for particular unfavorable adjudicatory decisions would be, of course, improper; again, I know of no evidence that such improprieties are a common occurrence within the executive branch.

18. Youngstown Sheet \& Tube Co. v. Sawyer, 343 U.S. 579, 587 (1952); see also Kendall v. United States ex rel. Stokes, 37 U.S. (12 Pet.) 524, 537 (1838) (when Congress directed payment to private mail carrier, President lacked authority to control or deuy payment).

19. For a discussion, see Strauss, supra note 3, at 640-67. 
safety of automobile occupants, giving due consideration to the benefits and costs of alternative systems." This is not a terribly precise mandate, but it is not so open-ended as to permit any set of decision criteria. The President, for instance, could not lawfully direct the Secretary of Transportation to disregard clear evidence that airbags are the inost efficient restraint system. In practical terms the question becoines one for courts to determine by reviewing the agency's final disposition of the inatter. To revert to the airbag exainple, a determination of the rationality of agency regulations will be based on the record coinpiled by the agency examined in light of the congressional mandate. ${ }^{20}$ Though the President's preferences in the matter inay not be irrelevant, they are not dispositive in determining the rationality of the action. ${ }^{21}$

It is within this rule-of-law framework, binding on executive and independent agency alike, that we inust evaluate the importance of the agency's status. Given the particular congressional processes and standards for making policy, the independent status of the agency can make a difference only to the extent that policy options are open to the administrator's and/or President's discretion.

This seems remarkably commonplace and would hardly bear mention except that it is sometime overlooked in discussions about independence, executive prerogatives, and the like. It will, however, be quickly observed that while Congress can specify the policy options and the standards that must be followed in inaking choices, it characteristically confers on agencies very broad discretion to choose among specified options-even on occasion to define what the policy options are. Control of this discretion is the bone of contention between protagoinsts of independence and executive prerogative.

This formulation is nevertheless misleading insofar as it suggests that control is a simple relationship well defined by the term "independence." Independence has never been legally defined in terms of functional control of discretion. The most we know froin Humphrey's Executor is that an independent officer is not subject to presidential re-

20. See Motor Vehicle Mfrs. Ass'n v. State Farm Mut. Auto. Ins. Co., 463 U.S. 29, 43-44 (1983) (Court will uphold a decision of less than ideal clarity if agency's record reveals a discernible decisionmaking path).

21. Just how much weight is given to presidential preference is one of those amorphous questions of judicial review that defies reliable generalization. In Chevron U.S.A. Inc. v. Natural Resources Defense Council, Inc., 467 U.S. 837, 865-66 (1984), the Court (per Justice Stevens) suggested that great deference was given to presidential preferences. In State Farm, on the other hand, the Court (per Justice White) appeared to give very little deference. 463 U.S. at 46-57. Chief Justice Burger, concurring in part and dissenting in part, noted that the Department of Transportation's changing views on vehicle safety standarcls reflected electoral changes. This was, he thought, "perfectly reasonable" as long as the agency "remains within the bounds established by Congress," which, contrary to the majority, he thought was the case in this instance. 463 U.S. at 57, 59. 
moval except for specified causes (such as "inefficiency, neglect of duty, or malfeasance im office"). Although this principle has been widely thought to imply as well that the officer is free from direct, formal control by the President-that being the point of denying a presidential removal power-the implication is open to debate. Because Humphrey's Executor permits removal for cause, one could argue that it is the President's prerogative to define and implement "cause," a power that presumably carries with it at least some power to give directions to the agency. ${ }^{22}$ But this is an argument I do not want to press, for it is not that significant as a practical matter. Whether or not the President has the authority to command, few question his power to influence agency pohicy in various direct and indirect ways, such as appointunent of members, budgetary controls and simple powers of "persuasion."23

The absence of a removal power imight occasionally handicap the effective use of such imfluence, but only for relatively short periods of time. Given the rapid turnover of agency inembers, a President need not wait long to use his appointment power to good advantage. ${ }^{24}$ The appointment power involves more than the occasional selection of individuals who are expected to have the desired outlook on relevant policy issues. The power to influence is not exhausted once the selection is made, for implicit in the selection itself is the choice of persons who will continue to be responsive to future presidential preferences. Respectful regard for signs of presidential preferences on policy issues is ensured not so much out of gratitude for the favor of the appointinent (though this may be a factor) as by the possibility of future rewards for faithful service (including other high appointments in the government). In the case of a

22. It has been argued that Humphrey's Executor does not preclnde presidential direction, backed by the sanction of removal ("for cause") for failure to comply. See Miller, supra note 3, at 94.

23. See Bruff, supra note 3, at 488-506; Robinson, On Reorganizing the Independent Regulatory Agencies, 57 VA. L. Rev. 947, 950-52 (1971).

24. On membership turnover and presidential appointment opportumities, see Robinson, supra note 23, at 951. It is important to note that simce Humphrey's Executor the President generally has been given power to designate agency chairmen. This power does not depend on a vacancy (the President can reappoint the chair from among sitting members), though vacancies usually make it possible for a President to select "fresh" faces from outside. Inspection of the United States Government Manual will show how frequently the occasion for appointing agency heads arises. For example, during the period of the Carter and Reagan administrations (January 1977 to the present) the FCC has had four different chairmen; the FTC, five; the NLRB, four; the SEC, four; and the CPSC, eight (coumting three acting chairs). Because of the special powers and prerogatives of ageucy chairmen, it is often not necessary to have the political loyalty or even active support of a majority of agency members. For illustrative instances, see M. DERTHICK \& P. QUIRK, THE POLITICS OF DEREGULATION 64-74 (1985). From personal experience I can report that the FCC's chairman and a handful of staff-usually selected by the chair-can and usually do exercise nearly total control over that agency's basic policy agenda. 
William Humphrey, a Coolidge appointee who had no expectation of favor froin the new administration of Roosevelt, the carrot of future benefit could not be a source of influence; only the stick of removal could work. But, realistically, how many Humphreys do we see in office beyond the first few months of a new presidential administration? More to the point, how many inore do we see in independent agency posts than we see in coinparable-level executive agency positions? We do not need to suppose that everyone who accepts an appointment to an agency expects tangible rewards for "good behavior" in order to imagine that most appointees will be reluctant to foreclose the possibility of reward by resisting clearly expressed presidential desires.

Of course, agency members are subject to a host of influences, including expected future rewards, froin sources other than the White House. Nevertheless, despite recurrent suggestions that independent agency members are soinehow specially vulnerable to such "outside" influenccs, ${ }^{25}$ there is no evidence that susceptibility to exogenous pressures or influences is a function of bureaucratic form. Can one imagine that the FCC is a greater friend to broadcasters than the Department of Agriculture is to farmers? And was there ever a time when the Department of Labor was less solicitous of organized labor than the NLRB? ${ }^{26}$

\section{III}

The effective limits on executive control of agencies are inore practical and political than legal. Whatever powers the President has to direct or influence agency administrators, circuinstances limit his ability to exercise those powers on a sustained basis. Again, this constraint is not a product of agency organization; at least it is not special to the case of independent agencies. Implementing effective presidential control of highway safety policies formulated by the National Highway Traffic Safety Association (NHTSA) (witlim the Department of Transportation) encounters the same kind of difficulties as would implementing presidential control of consumer safety policies formulated by the Consumer Product Safety Commission (CPSC) (an mdependent agency). This problein of control is endemic to all bureaucratic organization. Max Weber thought it an intractable problem:

25. For example, from the industries they regulate. See, e.g., M. Bernstern, Regulating BusinesS By INDEPENDENT CoMmission 126-63 (1955); Miller, supra note 3, at 83.

26. Frequently, of course, the agency's alliance with industry groups is simply a reflection of Congress's desigu for the program. See Robinson, The Federal Communications Commission: An Essay on Regulatory Watchdogs, 64 VA. L. REV. 169, 189-193 (1978). To the extent it is, there is even less reason to think that organizational change will materially alter the situation. 
Under normal conditions the power position of a fully developed bureaucracy is always overtowering. The "pohtical master" finds himself in the position of the "dilettante" who stands opposite the "expert," facing the trained official who stands within the management of administration. ${ }^{27}$

Weber's pessimism is overdone; political control of bureaucracy is not impossible-merely exceedingly difficult. The modern problem, though, is not quite the problem perceived by Weber. Weber perceived the difficulty of political control in terms of the disparate training and experience of the political officer (or public representative) and the bureaucrat - the problem of tlie "dilettante" trying to tell the expert low to regulate utility rates, allocate radio frequencies or regulate the money supply. That view is obsolete to the extent that it articulates the problem in terms of an allocation of power over technocratic clioices when the important modern question is control over political choices. It is not so mucli a question of deciding whether railroads should receive a rate $\mathrm{m}$ crease of ten percent or fifteen, whetlier AM radio cliannels sliould be ten kiloliertz or nine, wlietlier M-1, M-2 or M-3 sliould be the relevant indicator for measuring the money supply. It is more a question of deciding whether to allow rate increases, or even wlietlier to regulate rates, whether to put time and effort into reconfiguring the radio bandwidths, or wliether to increase or decrease the money supply. Behind tliese larger questions he the real stakes in the contest of control, and they depend hittle on developed expertise.

It isn't relative technocratic competence that gives the bureaucrat the edge; it is political will and time. The real advantage the bureaucrat enjoys is an ability (1) to give more sustained attention to a given problem, and (2) to extend the time liorizon of decisionınaking. Where a bureaucrat's time horizons may be measured in montlis and years, the average pohitical official's are measured in minutes and hours. It stands to reason that the average political official, who is likely to be in office for ouly a few years, would liave a more compressed sense of time than the bureaucrat, whose tenure may be an entire career. It is more than just a matter of time. Pohtical officials find tleir time distracted by the demands of countless different interest groups and constituents. Bureaucrats, particularly those at the lower echelons of government, have the luxury of specialization, and whether or not that specialization conveys any special expertise in regard to a particular political choice, it does confer a considerable advantage. Every deferral, delay or formality that

27. Weber, Bureaucracy, in From MAX Weber: EsSays on Sociology 232 (H. Gerth \& C. Mills eds. 1958). 
is required, by law or practical convenience, works to the administrator's advantage.

The low political visibility of routine administrative action makes it particularly difficult to obtain and maintain political attention, even from the politically appointed heads of bureaus or agencies. Imagine, then, the difficulties confronting a President. Sad to say, there is relatively little political credit to be obtained from sustanied involvenıent. Credit can be obtained fronı occasional efforts on behalf of some important pohtical constituency but, of course, it is just that kind of involvement that is inost difficult to justify in terms of the President's wider obligations to the public.

It is conimonly observed that the President's broad-based, national constituency puts him in a special position to constrain the rent-seeking behavior of narrow interest groups. ${ }^{28}$ So it does; unfortunately, the very saine position dininishes the President's pohtical incentives to beconie deeply involved or to sustain his involvement long enough to have effect. Except when the benefits of involvenient are highly visible to the general public or intensely enjoyed by a powerful constituency, they are unlikely to exceed the costs of intervening in an agency policy controversy in which contending interest groups have intense (or at least well-defined) preferences. As Harold Bruff aptly puts it, since the President bears only attenuated responsibility for agency decisions, "intervention is likely to be a zero-sun ganie fron his standpoint-he trades the pleasure of one constituency for the hostility of another." 29 Of course, no one supposes that the President personally can or should attenipt to control the bureaucracy. When the head of OSHA, FDA or a similar bureau within an executive departnient receives a call from "the White House," he can be fairly certain that the caller is not the President but a staff meniber, of probably middling rank in the White House hierarchy. And most imterventions into agency affairs will not come fron the White House at all (at least not directly); the executive influence will be filtered through multiple layers of departniental organization. Interventions into one agency's affairs may conie directly from another agency, such as the Department of Justice's Antitrust Division, which routinely performs a kind of monitoring role for regulatory agencies, or from the Office of Managenent and Budget (OMB), which performs a more general oversight role for the Executive Branch.

28. See, e.g., Bruff, supra note 3.

29. Bruff, Legislative Formality, Administrative Rationality, 63 TEX. L. REv. 207, 233 (1984); see also Aranson, Gellhorn \& Robinson, $A$ Theory of Legislative Delegation, 68 CoRNELL L. REv. 1, $41-43$ (1982). 
These are important forms of policy influence and direction, to be sure, but one sliould not suppose that individually or collectively these intervenors are simply representatives of the President. In fact these executive intervenors are themselves part of the administrative bureaucracy and as sucli present the same type of political control problems as the agencies they seek to influence. For instance, whien the OMB seeks to influence NHTSA (Department of Transportation) to alter certain safety standards, low do we know whicli set of executive officers and bureaucrats speaks for the President? If the Justice Departinent declines to support an EPA decision on appeal, which agency represents the executive branch?

Whatever the answer to these questions, one cannot avoid noticing that the organizational status of the agency inatters very little. Institutional inomitoring by one agency of another generally extends to independent and executive agencies alike. For example, the Justice Department intervenes in FCC proceedings as often as it does in those of the Department of Transportation (and exercises the same function witlr regard to judicial appeals of agency opinions). The one notewortly exception is the OMB regulatory review program, which does not include review of independent agency programs. ${ }^{30}$ This is perliaps unfortunate, but the omission has not prevented the President from influencing major policy imitiatives by other ineans.

If one scans the inajor events in the containment or rollback of administrative regulation over tlie past two administrations, ${ }^{31}$ it is striking how many of the imitiatives in fact involved independent agencies, which, under the "principle" of Humphrey's Executor, are nominally beyond the supposed reach of presidential power. Some of the imitiatives involved legislation and a joimt congressional/presidential initiative, as in the case of airline and surface transport deregulation. In each instance, however, the legislative action was preceded by independent agency initiatives by new agency nnembers appointed by the President and selected for their favorable views toward deregulation. ${ }^{32}$ More noteworthy for our purposes have been independent agency initiatives that were not the product of legislation. The FCC's substantial deregulation in the fields of cable television, broadcasting and telecommunications is a noteworthy

30. See generally DeMuth \& Ginsburg, White House Review of Agency Rulemaking, 99 HARv. L. REV. 1075 (1986); Strauss \& Sunstein, The Role of the President and OMB in Informal Rulemaking, 38 ADMIN. L. REv. 181 (1986).

31. For a general review and political commentary on recent deregulatory measures, focusing on airline, trucking and telecommunications, see M. DERTHICK \& P. QUIRK, supra note 24.

32. See id. at 58-61, 96-112; see also Levine, Revisionism Revised? Airline Deregulation and the Public Interest, LAw \& CONTEMP. ProBs., Winter 1981, at 179; Moore, Rail and Truck Reform: The Record So Far, Regulation, Nov.-Dec. 1983, at 33. 
example..$^{33}$

What is telling about these illustrations is that they fit closely with presidential programs in the Ford, Carter and Reagan administrations and yet did not require close presidential control of the direction of agency decisions. Selective presidential intervention through appointments, backed by presidentially supported legislation, proved remarkably effective. These forms of intervention are, of course, not limited to Executive Branch agencies.

\section{IV}

Nothing in the foregoing argument makes the case for independence. Quite the contrary; if (as I have suggested) nothing very important turns on organizational status, one might just as well adhere to the formal lines of organization identified in the Constitution. It coines down to a question of who has the burden of proof. I think this burden lies with those who want to change the status quo. This is a sensible general principle for allocating the burden of proof: advocates of change inust bear at least the burden of producing credible evidence showing that something worthwhile is at stake. That burden has not yet been met.

Critics might have a better case if they did not argue in terms of promoting greater executive control, but rather in terms of promoting clearer discourse about particular issues that are the subject of legisla-

33. In telecommunications, deregulation has been coincident with the introduction of competition; it was also partly aided by the 1982 breaknp of AT\&T at the insistence of the Justice Department. See generally G. Faulhaber, Telecommunications IN TURMoIl: Technology and PUblic Policy (1987) (analyzing the technological, economic and political currents in telecommunications and related industries from the 1960 s through divestiture). Somewhat iromically, the court that approved and now enforces the decice appears to be rather more regulation-minded than the FCC, which is still pursuing a predominantly deregulatory policy. See Robiuson, The Titanic Remembered: AT\&T and the Changing WTorld of Telecommunications (Book Review), 5 YALE J. ON REG. 517, 536 (1988).

In cable television, the FCC's virtually complete dismantling of the complex structure of regulation that it developed in the 1960s and early 1970s was modestly influenced (at least supported) by executive agencies-the Justice Departnent, the erstwhile Council on Wage-Price Stability, and tle National Telecommunications and Information Administration. Congress essentially ratified the effort in 1984 when it enacted the Cable Communications Policy Act of 1984, Pub. L. No. 98-549, 98 Stat. 2780 (codified at 47 U.S.C. $\$ \S 521-559$ (Supp. IV 1986)), desigued largely to limit local franchise regulation and incidentally to limit FCC regulation. See generally G. RoBINSON, E. Gellhorn \& H. Bruff, The Administrative Process 298-300, 386-96 (3d ed. 1986). In broadcasting, thc FCC's deregulation has becn given an occasional boost by the courts, see, e.g., FCC v. WNCN Listeners Guild, 450 U.S. 582 (1981), but nost of the effort has been an agency initiative with little overt support from the Executive Branch and some very heavy criticism from Congress. On the latter, see FCC and Congress Clash Over Proper Roles, 46 CONG. Q. WeEkLy REP. 479 (1988) (discussing tension between the congressional view that FCC regulation of broadcasting is needed and the Reagan adninistration and FCC view that deregulation of broadeasting is desirable). 
tive/executive interaction. If by eliminating the concept of "independence" we could rechannel debate from abstract and formalistic ideas of status to a more productive debate over particular issues of administrative policy-such as what Congress has inandated and the range of administrative discretion in carrying out that inandate-the game might well be worth the candle. Unfortunately, we have no reason to think that any such improvennent in the discourse about administrative policy issues would inaterially change present political behavior.

Abolishing independence as a concept of status miglit conceivably force Congress to think more clearly about the legal mandate it gives to agencies. My earlier example of the seatbelt regulations suggests the possibility of a clearer inandate. Mindful that it would be entrusting regulatory policy to an executive agency, Congress might clioose to be more specific about its directive in order to limit the degree of presidential control of agency policy. Such specificity is conceivable, but not probable. One could test its likelihood by coinparing congressional inandates to independent agencies with those to executive agencies. Holding other things constant, I doubt one would find any inaterial difference in the character of the mandates.

These expressions of skepticism leave ine im the uncomfortable position of appearing to defend independent administration as a distinctive form of bureaucratic life. The defense is not, however, one of pohtical primciple, merely one of conservation of energy. Unless we can expect soine improvement in functional political control of administrative policymaking, changing the status of the independent agencies will not repay the costs of institutional turmoil and of revising organization charts. 